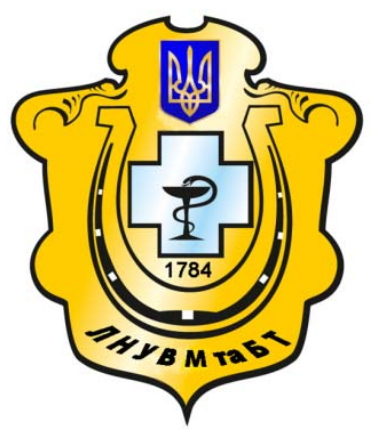

Науковий вісник Львівського національного університету ветеринарної медицини та біотехнологій імені С.З. Гжицького

Scientific Messenger of Lviv National University of Veterinary Medicine and Biotechnologies named after S.Z. Gzhytskyj

doi:10.15421/nvlvet7611

ISSN 2519-2701 print

ISSN 2518-1327 online

$\underline{\text { http://nvlvet.com.ua/ }}$

УДК 334.732.6

\title{
Теоретичні аспекти реалізації інтеграційних процесів в аграрному секторі на основі кластерів
}

\author{
Д.В. Сременко \\ eremenko-dv@mail.ru
}

Таврійський державний агротехнологічний університет,

пр. Б. Хмельнищького, 18, м. Мелітополь, Запорізька облизько, 72310, Украӥна

\begin{abstract}
Стаття присвячена аналізу теоретичних підходів щңодо формування інтеграційних зв'язків в аграрному секторі економіки Украйни за допомогою кластерів. Автор зазначає, що на даний момент має місие низка трактувань поняття «кластер», щчо сформовані у науковій та нормативно-правовій площчинах. Незважаючи на певні розбіжності у формулюваннях, невід'ємною складовою будь-якого кластеру є суб'єкти підприємницької діяльності, що намагаються підвищити рівень конкурентоспроможності виробництва за рахунок оптимізації системи міжгосподарських зв'язків, підвищення рівня ефективності використання наявного ресурсного потенціалу, запровадження науково обтрунтованих техніко-технологічних та організаційних рімень. Саме тому основу будь-якого кластеру мають складати представники підприємницької спільноти, щзо здійснюють свою діяльність в даному регіоні, а ї̈ конкурентоспроможність є критерієм ефективності функиіонування кластеру як інтегруючої структури. В статті підкреслено, щчо розвиток інтеграційних структур на базі кластерних об 'єднань сприятиме підвищенню рівня конкурентоспроможності суб'єктів аграрного підприємництва.

Автор зазначає, що переважна більшість позитивних аспектів даного прощесу пов язані з підвищенням якості використання наявного ресурсного потенціалу, насамперед за рахунок доступу до сучасних техніко-технологічних рімень, а також ӥхньої адаптаиії до умов та вимог конкретного регіону та суб'єкта господарювання. В статті наголошується на необхідності створення інноваційних аграрних кластерів, базою для яких мають бути регіональні науково-навчальні иентри. Автором обтрунтовуються такі напрями співпраці між науковим та бізнес-співтовариствами: розробка ексклюзивних техніко-технологічних схем організачії конкурентоспроможного виробниитва або адаптачія існуючих відповідно до потреб конкретного господарства; оптимізачія теоретико-методологічного забезпечення дослідження сучасних особливостей розвитку аграрного виробництва, враховуючи його багатоукладний характер; підготовка фахівців для організаціі ефективного ведення підприємницької діяльності, враховуючи специфіку малого та середнього аграрного підприємництва, а також сільськогосподарських підприємств сімейного типу на засадах високого рівня товарності; моніторинг процесів регіонального розвитку аграрного виробництва з метою визначення основних трендів функиіонування галузі.

Ключові слова: кластер, аграрне підприємничтво, інтеграчійні процеси, конкурентоспроможність, фермерські господарства, інновачійна діяльність, кадрове забезпечення.
\end{abstract}

\section{Теоретические аспекты реализации интеграционных процессов в аграрном секторе на основе кластеров}

\author{
Д.В. Еременко \\ eremenko-dv@mail.ru
}

Таврический государственный агротехнологический университет, пр. Б. Хмельниџкого, 18, г. Мелитополь, Запорожская облизько, 72310, Украина

Статья посвящена анализу теоретических подходов относительно формирования интеграционных связей в аграрном секторе экономики Украины с помощью кластеров. Автор отмечает, что на данный момент имеет место ряд трактовок понятия «кластер», сложившиеся в научной и нормативно-правовой плоскостях. Несмотря на некоторые различия в фор-

Citation:

Yeremenko, D. (2017). Theoretical aspects of integration processes in the agricultural sector based clusters. Scientific Messenger LNUVMBT named after S.Z. Gzhytskyj, 19(76), 56-60. 
мулировках, неотъемлемой составляющей любого кластера являются субъекты предпринимательской деятельности, которые пытаются повысить уровень конкурентоспособности производства за счет оптимизаиии системы межхозяйственных связей, повышения уровня эффективности использования имеющегося ресурсного потенциала, внедрения научно обоснованных технико-технологических и организачионных решений. Именно поэтому основу любого кластера должны составлять представители предпринимательского сообщества, осуществляюшие свою деятельность в данном регионе, а ее конкурентоспособность является критерием эффективности функционирования кластера как интегрируюшей структуры. В статье отмечается, что развитие интеграционных структур на базе кластерных объединений будет способствовать повышению уровня конкурентоспособности субъектов аграрного предпринимательства.

Автор отмечает, что подавляющее большинство положительных аспектов данного процесса связань с повышением качества использования имеющегося ресурсного потенциала, прежде всего за счет доступа к современньл техникотехнологическим решениям, а также их адаптации к условиям и требованиям конкретного региона и субъекта хозяйствования. В статье отмечается необходимость создания инновационных аграрных кластеров, базой для которых должнь быть региональные научно-учебные центры. Автором обосновываются следуюшие направления сотрудничества между научным и бизнес-сообществами: разработка эксклюзивных технико-технологических схем организации конкурентоспособного производства либо адаптация существуюших согласно потребностям конкретного хозяйства; оптимизация теоретико-методологического обеспечения исследования современных особенностей развития аграрного производства, учитывая его многоукладный характер; подготовка специалистов для организации эффективного ведения предпринимательской деятельности, учитывая специфику малого и среднего аграрного предпринимательства, а также сельскохозяйственных предприятий семейного типа на основе высокого уровня товарности; мониторинг процессов регионального развития аграрного производства с иелью определения основных трендов функиионирования отрасли.

Ключевые слова: кластер, аграрное предпринимательство, интеграционные прочессы, конкурентоспособность, фермерские хозяйства, инновационная деятельность, кадровое обеспечение.

\title{
Theoretical aspects of integration processes in the agricultural sector based clusters
}

\author{
D. Yeremenko \\ eremenko-dv@mail.ru \\ Tavria State Agrotechnological University, \\ 18 B.Khmelnitsky Ave., Melitopol, Zaporizhia obl. 72310, Ukraine
}

The article is devoted to analysis of theoretical approaches concerning the formation of integration relations in the agrarian sector of Ukraine's economy with the help of clusters. The author notes that at the moment has a number of interpretations of the concept «cluster» established in the scientific and regulatory dimensions. Despite some differences in wording, an essential component of any cluster are the subjects of entrepreneurial activity who are trying to raise the level of competitiveness of production due to optimization of the system of intereconomic communications, increasing the level of efficiency of the available resource potential, introduction of scientifically grounded technical-technological and organizational solutions. That is why the basis of any cluster should be representatives of the business community operating in the region, and its competitiveness is the criterion of efficiency of functioning of the cluster as an integrated structure. The article notes that the development of integration structures on the basis of cluster associations is to increase the level of competitiveness of subjects of agrarian entrepreneurship.

The author notes that the vast majority of the positive aspects of the process associated with improving the quality use of available resource potential, primarily due to access to modern technological solutions and adapting them to the conditions and requirements of a particular region and entity. The article notes the need to create agricultural innovation clusters, the basis for which should be regional research and training centers. The author substantiates the following directions of cooperation between scientific and business communities: development of exclusive technological schemes of the organization of competitive production or adaptation according to the needs of a particular economy; optimization, theoretical and methodological supply of the study of modern features of development of agricultural production, given its mixed character; training of specialists for organization of effective business activity, given the specificity of small and medium agricultural businesses and agricultural enterprises of family type on the basis of a high level of marketability; monitoring the processes of regional development of agricultural production with the aim of identifying the main trends in the functioning of the industry.

Key words: cluster, agro entrepreneurship, integration processes, competitiveness, farming, innovation, and staffing.

\section{Вступ}

Процес будівництва інтеграційних утворень на базі суб'єктів системи аграрного виробництва відбувається постійно, безперервно і отримує свій вияв у різноманітних формах залежно від тісноти зв'язків між членами-учасниками, мети, що ставить перед собою конкретне формування, а також організаційноправового статусу елементів, що його створюють. Як приклад можна навести міжгосподарські об'єднання кооперативно-корпоративного типів, обслуговуючі кооперативи, які включають в себе фізичних та юри- дичних осіб, агропромислові об'єднання тощо. Проте за сучасних умов набуває особливого значення активізація розвитку аграрного підприємництва на засадах кластерного підходу.

Актуальність теми. Проблематика оптимізації міжгосподарської співпраці суб'єктів аграрного підприємництва, а також напрями розвитку кластерного будівництва в аграрному секторі знайшли своє відображення в працях В.М. Гейця, В.К. Збарського, П.Т. Саблука, С.I. Соколенка та ін. Проте, на нашу думку, потребують додаткового дослідження питання, пов'язані із вивченням теоретичних аспектів виник- 
нення кластерних утворень на базі регіональної підприємницької спільноти (Sokolenko, 2004; Heiets, 2008; Sabluk and Kropyvko, 2010; Karpenko and Shpak, 2012; Zbarskyi, 2013; Kurbanov, 2015).

Мета і завдання дослідження. Метою дослідження $\epsilon$ вивчення теоретичних підходів щодо процесу кластерного будівництва в системі аграрного підприємництва. Для досягнення мети було сформульовано такі завдання: проаналізувати наукові підходи щодо визначення терміну «кластер», дослідити особливості створення кластерних структур, проаналізувати проблеми та перспективи формування регіональних кластерів на базі суб'єктів малого та середнього аграрного бізнесу.

\section{Матеріал і методи дослідження}

В процесі дослідження було використано такі методи: абстрактно-логічний, монографічний, порівняльного аналізу.

\section{Результати та їх обговорення}

Варто зазначити, що на даний момент має місце низка трактувань поняття «кластер», що сформовані у науковій та нормативно-правовій площинах. В науковій літературі існує низка визначень, що характеризують форми співпраці підприємницьких структур із державними інститутами в масштабі конкретного регіону (табл. 1).

\section{Порівняльна характеристика наукових підходів щодо визначення економічної}

Таблиця 1 сутності поняття «кластер»

\begin{tabular}{|c|c|c|}
\hline Визначення & Мета діяльності & $\begin{array}{c}\text { Особливості } \\
\text { функціонування }\end{array}$ \\
\hline $\begin{array}{l}\text { Кластер - це організація територіально взаємопов'язаних } \\
\text { відносинами співробітництва підприємств та організацій, що } \\
\text { об'єднані навколо науково-освітнього центру, пов'язана } \\
\text { партнерськими відносинами із державними та муніципаль- } \\
\text { ними органами управління }\end{array}$ & $\begin{array}{l}\text { Підвищення конкуренто- } \\
\text { спроможності підприємств, } \\
\text { регіону та національної еко- } \\
\text { номіки }\end{array}$ & $\begin{array}{l}\text { Наявність наукових } \\
\text { центрів як членів }\end{array}$ \\
\hline $\begin{array}{l}\text { Кластер - це географічна концентрація подібних, суміжних } \\
\text { або додаткових підприємств } 3 \text { активними каналами для } \\
\text { бізнес-транзакцій, комунікацій та діалогу, що поділяють } \\
\text { спеціалізовану інфраструктуру, робочі ринки та послуги та } \\
\text { мають спільні можливості або загрози. }\end{array}$ & $\begin{array}{l}\text { Вирішення спільних органі- } \\
\text { заційних } \\
\text { проблем }\end{array}$ & $\begin{array}{l}\text { Потенційна можливість } \\
\text { для включення широко- } \\
\text { го кола підприємців }\end{array}$ \\
\hline $\begin{array}{l}\text { Промисловий кластер - це набір виробництв, чиї взаємовід- } \\
\text { носини представляють собою «покупець-постачальник» та } \\
\text { «постачальник - покупець», або загальні технології, загальні } \\
\text { покупці, або канали розподілу, або загальні людські ресурси }\end{array}$ & $\begin{array}{l}\text { Оптимізація } \quad \text { техніко- } \\
\text { технологічних та організацій- } \\
\text { них ланцюгів }\end{array}$ & $\begin{array}{l}\text { Галузева обмеженість } \\
\text { членів }\end{array}$ \\
\hline $\begin{array}{l}\text { Регіональний кластер - це промисловий кластер, в якому } \\
\text { фірми-члени перебувають у безпосередній близькості один } \\
\text { до одного }\end{array}$ & $\begin{array}{l}\text { Оптимізація } \\
\text { технологічних та організацій- } \\
\text { них ланцюгів }\end{array}$ & $\begin{array}{l}\text { Регіональна } \\
\text { ність членів }\end{array}$ \\
\hline $\begin{array}{l}\text { Регіональний індустріальний кластер - інноваційна структу- } \\
\text { ра, що формується в регіоні на основі концентрації мереж } \\
\text { виробників, постачальників і споживачів, пов’язаних спіль- } \\
\text { ними схемами виробництва і реалізації продукції, пробле- } \\
\text { мами регіонального відтворення та розвитку інституційного } \\
\text { середовища }\end{array}$ & $\begin{array}{l}\text { Налагодження кооперативної } \\
\text { взаємодії між суб'єктами } \\
\text { регіональної економіки для } \\
\text { реалізації їх власних цілей та } \\
\text { конкурентних переваг регіону }\end{array}$ & $\begin{array}{l}\text { Відсутність обмежень } \\
\text { за галузевими та тери- } \\
\text { торіальними ознаками }\end{array}$ \\
\hline $\begin{array}{l}\text { Кластер - це різновид великих мереж підприємницького } \\
\text { типу, що сконцентровані на географічно визначеній терито- } \\
\text { piї. }\end{array}$ & $\begin{array}{l}\text { Удосконалення міжгосподар- } \\
\text { ських відносин, рівня взаємо- } \\
\text { дії між суб'єктами підприєм- } \\
\text { ницької діяльності }\end{array}$ & $\begin{array}{l}\text { Організаційно-правова } \\
\text { обмеженість } \quad \text { членів } \\
\text { кластерів }\end{array}$ \\
\hline
\end{tabular}

Джерело: Дослідження автора

Незважаючи на певні розбіжності у формулюваннях, невід'ємною складовою будь-якого кластеру є суб’єкти підприємницької діяльності, що намагаються підвищити рівень конкурентоспроможності виробництва за рахунок оптимізації системи міжгосподарських зв'язків, підвищення рівня ефективності використання наявного ресурсного потенціалу, запровадження науково обгрунтованих техніко-технологічних та організаційних рішень. Саме тому основу будь-якого кластеру мають складати представники підприємницької спільноти, що діють в даному регіоні, а іiі конкурентоспроможність є критерієм ефективності функціонування кластеру як інтегруючої структури.

Водночас географічна обмеженість кластеру i, як наслідок, суттєвий вплив його розвитку на соціально- економічний стан регіону обумовлює необхідність участі державних інститутів не тільки як засобу легітимізації даного об'єднання, а й форми контролю за організацією використання консолідованих обсягів матеріальних, грошових та трудових ресурсів. Особливо важливим $є$ факт наявності даних структур в системі кластерів, що об'єднують представників малого та середнього аграрного бізнесу і діяльність яких значною мірою визначає характер розвитку сільських територій, рівень зайнятості на селі, ступінь добробуту сільського населення, демографічний вектор в сільській місцевості на ін.

Беручи до уваги вищевказані аспекти функціонування кластеру як специфічної структури, ми погоджуємося із думкою К.О. Ісланкіної відносно того, що 
проблемне поле кластерного підходу складають не тільки дослідження питань конкурентоспроможності виробництва на рівні підприємства, галузі та національної економіки, а й аналіз та розробка загальнонаціональної та регіональної промислової політики, дослідження інноваційних аспектів діяльності суб'єктів господарювання та взаємодії мереж бізнесу, науки, державних і фінансових інститутів.

Аналізуючи характер ефекту від запровадження даної моделі співробітництва бізнес-структур та державних установ, варто зазначити, що переважна більшість позитивних аспектів даного процесу пов'язані iз підвищенням якості використання наявного ресурсного потенціалу, насамперед за рахунок доступу до сучасних техніко-технологічних рішень, а також їхньої адаптації до умов та вимог конкретного регіону (що $є$ особливо важливим для аграрного сектору) та суб'єкта господарювання. Окремо слід розглядати організаційну складову позитивного значення кластеру для його членів-учасників, яка пов'язана із здобуттям синергічного ефекту від взаємовигідного системного розвитку, спільно вирішуючи проблеми розвитку один одного. Набуває особливої значущості спроможність членів-учасників кластеру створювати та використовувати інформаційний капітал, вартість та споживна вартість якого є відносною більшою мірою, ніж матеріальних, фінансових та трудових ресурсів.

Уцьому зв'язку досить популярним $є$ термін «інноваційний кластер», до складу якого зазвичай входять виробники певного виду продукції та послуг, постачальники сировини, матеріалів, обладнання, технологій, комерційні структури. Основи співробітництва, взаємодію і внутрішньомережеві зв'язки між організаціями, що входять до складу кластера, визначають відповідними угодами. Найуспішніше інноваційні кластери формуються там, де здійснюється інноваційний прорив у галузі виробництва, технології або послуг (Kniazevych and Britchenko, 2015).

Швидкість отримання інформації від членів кластеру та в процесі моніторингу інформаційного середовища, результативність іiі обробки (здобуття необхідних результатів в процесі аналітичної діяльності) за сучасних умов значною мірою впливає на рівень конкурентоспроможності суб'єкта аграрного підприємництва, незважаючи на організаційно-правовий статус. В даному аспекті особливо важливим $є$ забезпечення взаємовигідної співпраці між представниками аграрного підприємництва (зокрема фермерськими господарствами) та регіональними науковонавчальними центрами, діяльність яких за сучасних умов здійснюється на принципах самовиживання. Скорочення державного замовлення на цілу низку спеціальностей і відповідно державного фінансування вищої школи в регіонах, створює реальну загрозу для подальшого існування даних закладів, що в свою чергу, вимагає пошуку нових засобів для забезпечення свого існування на засадах сталого розвитку. За цих обставин перспективними напрямами продуктивної співпраці між науковим та бізнесспівтовариствами є, на нашу думку, такі:

- розробка ексклюзивних техніко- ного виробництва або адаптація існуючих відповідно до потреб конкретного господарства;

оптимізація теоретико-методологічного забезпечення дослідження сучасних особливостей розвитку аграрного виробництва, враховуючи його багатоукладний характер;

підготовка фахівців для організації ефективного ведення підприємницької діяльності, враховуючи специфіку малого та середнього аграрного підприємництва, а також сільськогосподарських підприємств сімейного типу на засадах високого рівня товарності;

моніторинг процесів регіонального розвитку аграрного виробництва 3 метою визначення основних трендів та прогнозування подальших перспектив функціонування галузі.

Практична реалізація кластерного підходу щодо забезпечення конкурентоспроможного функціонування суб'єктів аграрного підприємництва дозволяє створити умови для системного розвитку значної кількості суб'єктів господарювання в межах окремого регіону, проте, реалізуючи дану модель інтеграційної взаємодії наукових, бізнесових та державницьких інституцій, необхідно, на нашу думку, дотримуватися таких принципів.

1. Відкритість кластеру, стимулювання розширення кола членів-учасників, гнучкість структури, наявність тісних взаємозв'язків між членамиучасниками.

2. Домінування приватного бізнесу як об'єкту реалізації проектних рішень і забезпечення конкурентоспроможності суб'єктів підприємницької діяльності як основної мети їхнього запровадження.

3. Створення конкурентних умов між членамиучасниками кластеру, стимулювання попиту на науково-інформаційну продукцію серед підприємців та забезпечення пропозиції інноваційно-інформаційної продукції з боку представників наукової спільноти.

4. Першочергова орієнтація на стимулювання економічного та соціального розвитку регіону, в якому зосереджена «критична маса» учасників-членів кластеру, участь у відповідних державних програмах та заходах.

Варто підкреслити, що сам процес створення та подальшого функціонування інтегрованих утворень кластерного типу є досить складним, кожен кластер має власні специфічні особливості виникнення та вектора розвитку і на характер його становлення здійснюють свій вплив комплекс факторів, дія яких не завжди має позитивний характер. До основних проблем практичної реалізації кластерів як форми консолідованого розвитку державних та бізнес-інститутів в аграрній сфері відносять такі:

- проблеми із визначенням цільової галузі або суб'єкта господарювання, що мають стати основою розвитку кластеру;

- незадовільний стан розвитку соціальноекономічної інфраструктури, логістичноінформаційного забезпечення на рівні регіону;

- різний рівень конкурентоспроможності підприємницьких структур - учасників кластеру; 
- відсутність належного професійнокваліфікаційного рівня, а також практичних навичок та умінь для організації кластерних об'єднань та забезпечення ефективної взаємодії між учасниками протягом тривалого періоду;

- низький рівень інвестиційної привабливості об'єднань, що включають в себе членів, що різняться за організаційно-правовими та мотиваційними критеріями;

- відсутність належної інституційної структури кластеру як форми вираження інтересів своїх членів, а також проблеми із його інтеграцією в систему загальнодержавних соціально-економічних заходів;

- ізолююче-обмежуючий вплив периферійного розміщення на рівень конкурентоспроможності суб'єктів малого аграрного бізнесу.

Необхідно враховувати той факт, що кожен кластер $\epsilon$ унікальним утворенням, що формується під впливом соціально-економічних факторів, які обумовлюються загальнонаціональними та регіональними особливостями розвитку всіх складових даного утворення (підприємництва, державних інститутів, наукових центрів тощо).

\section{Висновки}

В статті проаналізовано теоретичні підходи до процесу кластерного будівництва в системі аграрного підприємництва. За результатами дослідження доведено, що термін «кластер» трактується вітчизняними науковцями 3 різних позицій. Обгрунтовано необхідність забезпечення розвитку конкурентоспроможного аграрного виробництва за рахунок створення інноваційних кластерів. Зазначається важлива роль регіональних науково-навчальних центрів у підвищенні рівня конкурентоспроможності суб'єктів аграрного підприємництва.
Перспективи подальших досліджень. В подальшому планується дослідити перспективи створення інноваційних кластерів на рівні конкретного регіону. Передбачається проаналізувати вплив кластерних структур на ступінь конкурентоспроможності суб'єктів малого аграрного підприємництва, зокрема фермерських господарств.

\section{Бібліографічні посилання}

Heiets, V. (2008). Klastery i merezhevi struktury v ekonomitsi - tema dosyt tsikava, ale na sohodni shche do kintsia ne vyvchena. Ekonomist. 10, 10-11 (in Ukrainian).

Zbarskyi, V.K. (2013). Upravlinnia rozvytkom malykh silskohospodarskykh pidpryiemstv. Visnyk Sumskoho natsionalnoho ahrarnoho universytetu. Finansy i kredyt. 1, 108-115 (in Ukrainian).

Karpenko, O.O., Shpak, O.S. (2012). Osoblyvosti formuvannia klasteriv v Ukraini. Vodnyi transport. 2, 83-87 (in Ukrainian).

Kniazevych, A.O., Britchenko, I.H. (2015). Klasternyi pidkhid do stvorennia innovatsiinoi infrastruktury krainy. Naukovyi visnyk Mukachivskoho derzhavnoho universytetu. Ser.: Ekonomika. 2(1), 24 29 (in Ukrainian).

Kurbanov, A.A. (2015). Klasternyj pohod v formirovanii innovacionnoj jekonomiki. Aktual'nye voprosy jekonomicheskih nauk. 44, 43-46 (in Russian).

Sabluk, P.T., Kropyvko, M.F. (2010). Klasteryzatsiia yak mekhanizm pidvyshchennia konkurentospromozhnosti ta sotsialnoi spriamovanosti ahrarnoi ekonomiky. Ekonomika APK. 1, 3-12 (in Ukrainian).

Sokolenko, S.I. (2004). Klastery v hlobalnii ekonomitsi. K.: Lohos (in Ukrainian).

Стаття надійшла до редакиії 2.03.2017 